\title{
C-banding karyotype and NORs analyse in eight species of Bary- peithes Duval from Central Europe (Coleoptera, Curculionidae, Entiminae)
}

\author{
Lachowska Dorota $^{1 *}$, Maria RożeK ${ }^{1}$ and Milada Holecová ${ }^{2}$ \\ ${ }^{1}$ Department of Experimental Zoology, Institute of Systematics and Evolution of Animals, Polish Academy of Sci- \\ ences, Sławkowska17, PL 31-016 Kraków, Poland. \\ ${ }^{2}$ Department of Zoology, Comenius University, Mlynská dolina B-1, SK 842-15 Bratislava, Slovakia.
}

\begin{abstract}
Karyotypes of eight species belonging to the genus Barypeithes were studied using standard Giemsa staining, AgNOR- and C-banding techniques. The species studied share almost the same chromosome number $2 \mathrm{n}=22\left(10+\mathrm{Xy}_{\mathrm{p}}\right)$ with exception of endemic Barypeithes liptoviensis which possesses 26 chromosomes $\left(12+\mathrm{Xy}_{\mathrm{p}}\right)$. The karyotype of Barypeithes pellucidus is characterized by the presence of one to six B chromosomes clearly distinguishable from the regular members of the complement. In all examined species heterochromatin visualized by Cbanding, is found to be limited almost to the pericentromeric region of all chromosomes with differences in their amount. The wide C-bands visible during mitotic metaphase are observed in five species whereas a small blocks of heterochromatin visible during mitotic prophase are found in three species. Also the one Ag-stained NOR situated in the sex chromosomes is visible during mitotic and meiotic prophases.
\end{abstract}

Key words: C-bands, chromosome number, Coleoptera, Curculionidae, karyotype, NORs

\section{INTRODUCTION}

The genus Barypeithes Duval includes about 37 species distributed in Palaearctic region (mainly in Central and Southern Europe and in North Africa). One species (Barypeithes pellucidus) was introduced to North America and can be a pest of strawberry plantations (Cross et al. 2001) These weevils are typical inhabitants of leaf litter in deciduous, mixed forests, parks and gardens. Adults feed on various herbaceous plants and have night activity (DieCKMANn 1980; SMRECZYŃski 1966). The apterous character of these beetles greatly reduces their capacity for dispersion. So far chromosome numbers have been studied only in four species and C-bands are known in chromosomes of one species (TACHENouCHI 1965; HoleCOvá et al. 1999; 2002).

The present report deals with C-banding chromosome patterns and localization of active NORs in eight species of the genus Barypeithes from Central Europe and is a continuation of our investigation on karyology of Palaearctic weevils.

\footnotetext{
* Corresponding author: Fax + 4812 422-42-94, e-mail: lachowska@isez.pan.krakow.pl.
}

\section{MATERIALS AND METHODS}

For the cytogenetic study, adults of both sexes were collected in forest habitats of Western and Central Slovakia in May and June 2004 (Table 1). Gonads were dissected in several drops of hypotonic $1 \%$ sodium citrate solution under a stereomicroscope. The organs were transferred in colchicine-hypotonic solution $(0.005 \% \mathrm{w} / \mathrm{v}$ colchicine in $1 \%$ sodium citrate solution) and left for 45-60 $\mathrm{min}$ at room temperature. The gonads were fixed according to the method described by RożEK (1994) with minor modification (RożEK and LACHOwsKa 2001). C-bands were determined using modifications of the procedure described by Sumner (1972). The squashed slides were treated with a $0.3 \mathrm{~N} \mathrm{HCl}$ for $1 \mathrm{~min}$ at $20-23^{\circ} \mathrm{C}$, followed by thorough rinsing with distilled water and dried. The slides were placed in a freshly prepared solution of $5 \%$ barium hydroxide at $20-23^{\circ} \mathrm{C}$ for $1.5 \mathrm{~min}$. Next, they were rinsed with distilled water and incubated in $2 \mathrm{xSSC}$ at $50^{\circ} \mathrm{C}$ for $1 \mathrm{~h}$. Dry slides were stained with $4 \%$ Giemsa phosphate buffer (pH 6.8) for 10 to 20 min.

For the NOR silver staining the method described by Howell and Black (1980) was used with some modifications. A brief outline of the 
Table 1 - Chromosomally examined species of weevils.

\begin{tabular}{|c|c|c|}
\hline Species & Geographic source and date of collection & Chromosome number \\
\hline $\begin{array}{l}\text { Barypeithes albinae } \\
\text { (Formánek 1903) }\end{array}$ & $\begin{array}{l}\text { SW Slovakia, Trnavská pahorkatina hills, Lindava Nature Reserve, } \\
\text { May 31, } 2004\end{array}$ & \multirow{8}{*}{ 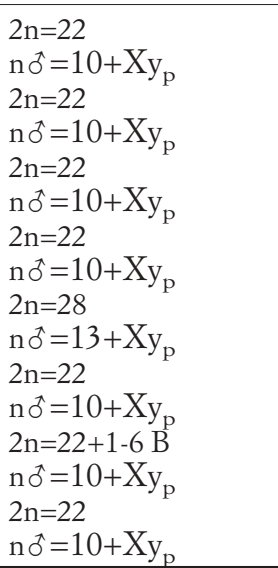 } \\
\hline $\begin{array}{l}\text { Barypeithes chevrolati } \\
\text { (Boheman 1843) }\end{array}$ & $\begin{array}{l}\text { SW Slovakia, Malé Karpaty Mts., Devínska Kobyla Nature Reserve, } \\
\text { May 7, } 2004\end{array}$ & \\
\hline $\begin{array}{l}\text { Barypeithes formaneki } \\
\text { (Fremuth 1971) }\end{array}$ & $\begin{array}{l}\text { SW Slovakia, Malé Karpaty Mts., Svätý Jur, } \\
\text { May 20, } 2004\end{array}$ & \\
\hline $\begin{array}{l}\text { Barypeithes interpositus } \\
\text { (Roubal 1920) }\end{array}$ & $\begin{array}{l}\text { C Slovakia, Zvolenská kotlina basin, Príboj Nature Reserve, } \\
\text { June 10, } 2004\end{array}$ & \\
\hline $\begin{array}{l}\text { Barypeithes liptoviensis } \\
\text { (Weise 1894) }\end{array}$ & $\begin{array}{l}\text { C Slovakia, Zvolenská kotlina basin, Príboj Nature Reserve, } \\
\text { June 10, } 2004\end{array}$ & \\
\hline $\begin{array}{l}\text { Barypeithes mollicomus } \\
\text { (Ahrens 1812) }\end{array}$ & SW Slovakia, Malé Karpaty Mts., Naháč, May 31, 2004 & \\
\hline $\begin{array}{l}\text { Barypeithes pellucidus } \\
\text { (Boheman 1834) }\end{array}$ & SW Slovakia, Malé Karpaty Mts., Bratislava, May 26, 2004 & \\
\hline $\begin{array}{l}\text { Barypeithes purkynei } \\
\text { (Fremuth 1965) }\end{array}$ & $\begin{array}{l}\text { C Slovakia, Vtáčnik Mts., Vtáčnik Nature Reserve, } \\
\text { June 29, } 2004\end{array}$ & \\
\hline
\end{tabular}

technique is as follows: two solutions $\mathrm{A}$ and $\mathrm{B}(\mathrm{A}$ a silver nitrate solution, $4 \mathrm{~g}$ of $\mathrm{AgNO}_{3}$ is dissolved in $8 \mathrm{ml}$ of deionized water; $\mathrm{B}$ - a gelatin solution with formic acid, $1 \mathrm{~g}$ gelatin is dissolved in $50 \mathrm{ml}$ distilled water, with stirring and gentle heating. When the gelatin is dissolved, $0.5 \mathrm{ml}$ of formic acid is added) were immediately dropped onto the slides in the proportion $2 \mathrm{~A}: 1 \mathrm{~B}$. Next the slides were covered with a coverslip, placed into dark humid box in a thermostat, and incubated at $50^{\circ} \mathrm{C}$ for $25 \mathrm{~min}$, when the mixture turned a golden brown colour. The preparations were then rinsed in tap water, in distilled water, air-dried and mounted with Euparal. Chromosomes were classified according to LEVAN et al. (1964).

Observations of chromosomes and photomicrographs were made using a Jenaval light microscope (C. Zeiss, Jena). The material is deposited in the Institute of Systematics and Evolution of Animals (Kraków).

\section{RESULTS AND DISCUSSION}

Seven of eight analysed species share the diploid complement of 22 chromosomes and a sex mechanism of the parachute type $\left(\mathrm{Xy}_{\mathrm{p}}\right)$ (Figs 1a-d, 1g-h, 2a-e). Only endemic Barypeithes liptoviensis possesses 26 chromosomes $\left(12+\mathrm{Xy}_{\mathrm{p}}\right)$ (Figs 1e-f), and also showes some morphological differences in comparison with other congeneric species. The standard chromosome number of three species is in agreement with that given by us previously (HoLECová et al. 1999).

The diploid chromosome number $2 n=22$ is the most characteristic of weevils and seems to be ancestral for Curculionidae - group Adelognathi
(Holecová et al. 2002). In weevils there is a very wide array of magnitudes from the smallest dotlike y chromosomes to the largest heterochromosomes $\mathrm{X}$ or autosomes. The great majority of chromosomes in Curculionidae have median and submedian centromeres, following the general rule of metacentry of the beetle chromosomes and also tendency towards symmetrization of karyotypes has been observed (LACHOwskA et al. 1998). The parachute-like system is dominant in weevils and has been found in each subfamily.

The presence of one to six B chromosomes is very interesting in the karyotype of Barypeithes pellucidus (Fig.2c-d). They are clearly distinguishable from the regular members of the complement. The size of these supernumerary chromosomes is approximately the same or a little smaller than that of heterochromosomes. The behaviour of the Bs at the first meiotic metaphase is variable - the association of a pair of Bs, incorporation with the $\mathrm{Xy}_{\mathrm{p}}$ or / and association with the autosomes can be observed. The incorporation of the $\mathrm{B}$ chromosome to the sex bivalent creating a tripartite complex is noticed in Curculionidae for the first time. The plates of mitotic metaphase and meiotic metaphase $I$ in $B$. pellucidus reveal the largely euchromatic B-chromosomes, while in other species they are frequently heterochromatic. Of the total number of up to 600 species of Curculionidae examined karyologically, only four species with supernumerary chromosomes were hitherto described (ENNIS 1972; SMITH and Brower 1974; Dey 1989; Holecová et al. 2005).

In all examined species, heterochromatin visualized by C-banding is found to be limited almost to the pericentromeric region of all chromosomes with differences in their amount. Sometimes also 


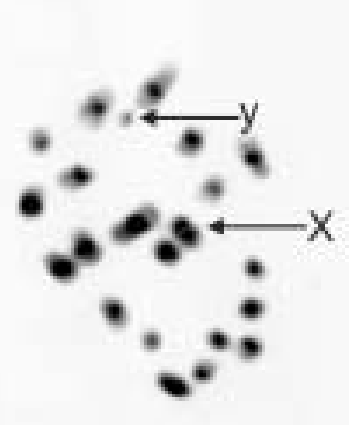

a

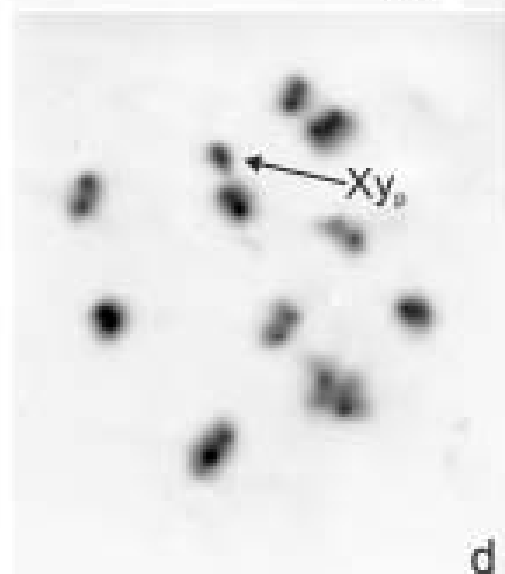

d

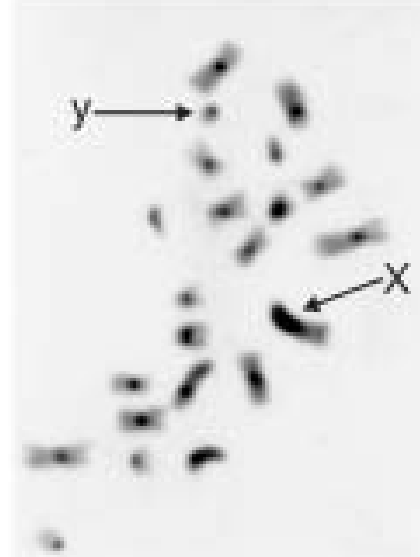

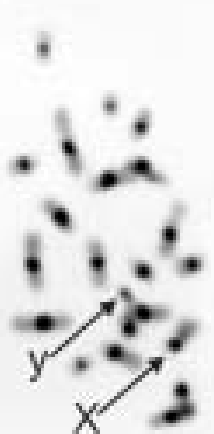

b

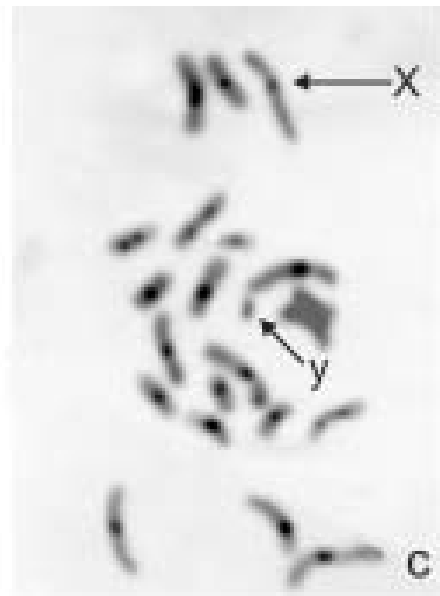

C

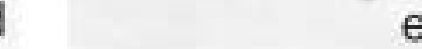

e

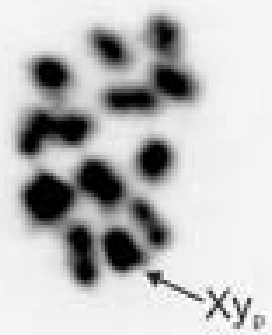

$f$

g

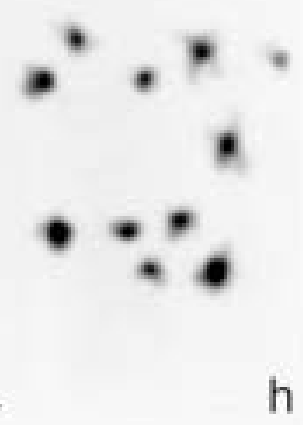

Fig. 1. - The chromosomes of Barypeithes species with a big amount of heterochromatin: (a) mitotic metaphase $B$. chevrolati, (b) mitotic metaphase of B. formaneki, (c) mitotic metaphase of B. interpositus, (d) metaphase I of mitotic metaphase of B. interpositus, (e) mitotic metaphase of B. liptoviensis, (f) metaphase I of mitotic metaphase of $B$. liptoviensis, (g) mitotic metaphase of B. mollicomus, (h) metaphase I of B. mollicomus. Bar equals $5 \mu \mathrm{m}$.

intercalary and terminal bands are visible. A wide C-bands appearing during all nuclear division are observed in five species: Barypeithes chevrolati, $B$. formaneki, B. interpositus, B. liptoviensis and B. mollicomus.
Barypeithes chevrolati - the karyotype consists of three the longest, metacentric pairs of autosomes, two shorter subtelocentric and five the shortest, meta- and subtelocentric. The centromeric C-positive segments are visible on all auto- 
somes during mitotic metaphase. The subtelocentric chromosome $\mathrm{X}$ of middle size possesses also intercalary C-band on the longer arm, while the dot-like y heterochromosome is characterized by the presence of a small amount of heterochromatin (Fig. 1a).

Barypeithes formaneki - three the longest pairs of autosomes are meta- and submetacentric, two middle size are subtelocentric, five the shortest are meta- and submetacentric. The chromosome $\mathrm{X}$ of middle size is subtelocentric, and the submetacentric $\mathrm{y}$ is the smallest element in the set. The bands of heterochromatin are visible in centromeric regions of all autosomes and chromosome $\mathrm{X}$, and on the long arm of chromosome $\mathrm{y}$ (Fig. 1b).

Barypeithes interpositus - the karyotype comprises autosomes with no differences in length and morphology with median or submedian centromeres. The pericentromeric C-bands are observed with exception of two pairs of autosomes with intercalary bands on both arms. The chromosome $\mathrm{X}$ is the longest, metacentric whereas the $\mathrm{y}$ is meta- or submetacentric and almost all euchromatic (Figs 1c-d).

Barypeithes liptoviensis - eleven pairs of meta-, submeta-, and one smaller subtelocentric autosomes are observed with centromeric C-bands. One pair possesses also intercalary C-bands on both arms. The chromosome $\mathrm{X}$ is the longest, metacentric with pericentric and terminal heterochromatin on one arm, the dot-like chromosome y is almost whole heterochromatic (Figs 1e-f).

Barypeithes mollicomus - the asymmetric karyotype is observed with seven pairs of metaand submetacentric autosomes and three pairs of subtelocentric autosomes. The constitutive heterochromatin has a centromeric location in all autosomes. The chromosome $\mathrm{X}$ is long, submetacentric with heterochromatic short arm, the $y$ chromosome is the shortest, metacentric with centromeric C-bands (Figs 1g-h).

In five examined species with a big amount of heterochromatin the C-banding technique reveals different banding pattern on mitotic chromosomes which is characteristic for each species and it could be used in taxonomic evaluations.
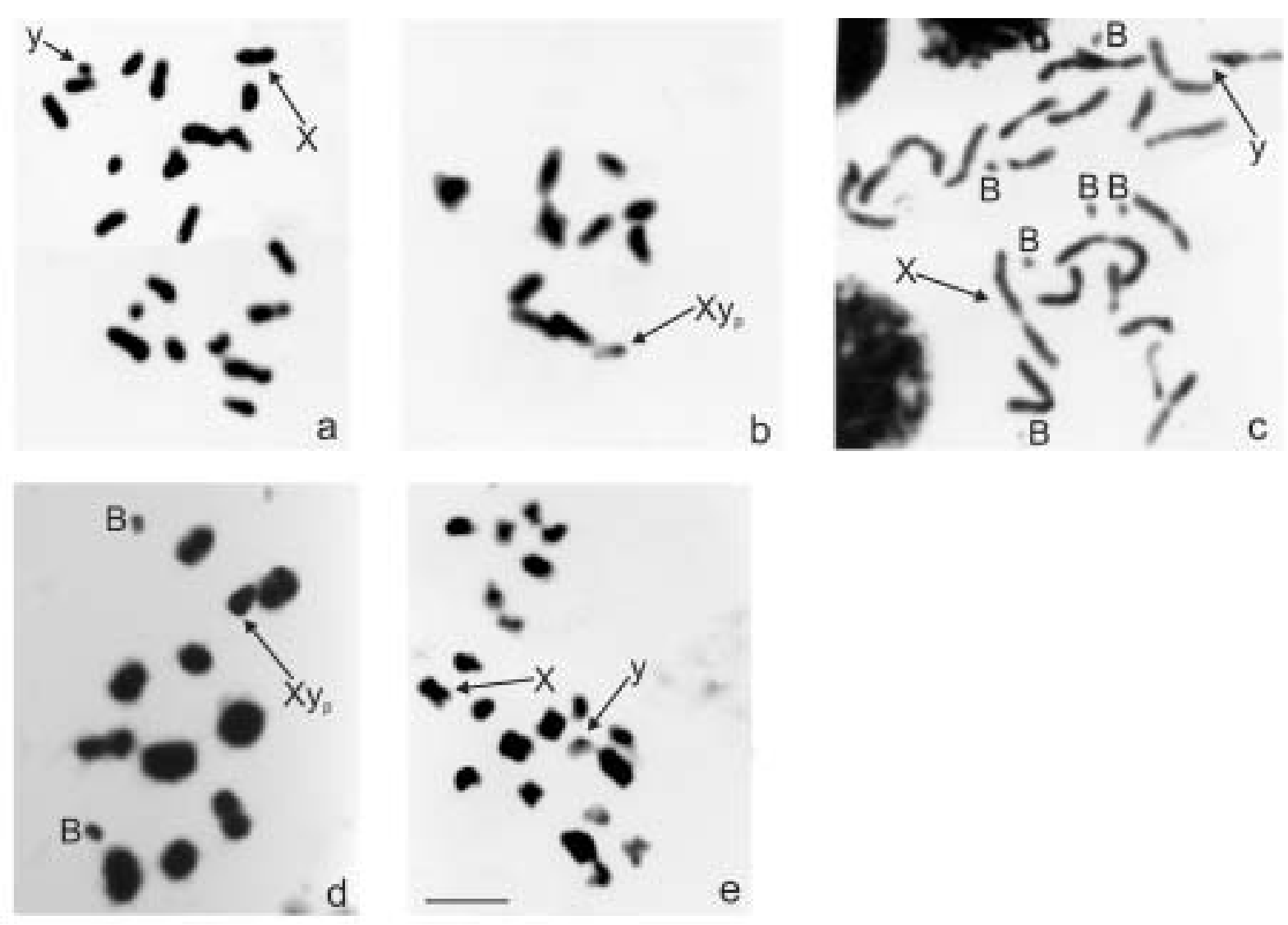

Fig. 2. - The chromosomes of Barypeithes species with a small amount of heterochromatin: (a) mitotic metaphase of B. albinae, (b) metaphase I of B. albinae, (c) mitotic metaphase of B. pellucidus, (d) metaphase I of B. pellucidus, (e) mitotic metaphase of B. purkynei. Bar equals $5 \mu \mathrm{m}$. 
A small blocks of heterochromatin visible only during prophase stages are found in three species: Barypeithes albinae, B. pellucidus, and B. purkynei.

Barypeithes albinae - the symmetric karyotype with median or submedian centromeres and with dot-like chromosome y is clearly defined (Figs 2ab). A small amount of heterochromatin is visible during mitotic and meiotic prophases and weakly visible or undetectable during mitotic metaphase, diakinesis, metaphase I and II.

Barypeithes pellucidus - the karyotype is composed mainly of metacentric and submetacentric autosomes with slight differences in size. Also the B-chromosomes are observed. The chromosome $\mathrm{X}$ is long, metacentric while the $\mathrm{y}$ is the smallest element in the set with the median position of centromere. A small heteropycnotic parts of centromeric localization are observed (Fig. 2c-d).

Barypeithes purkynei - seven pairs of metaand submetacentric autosomes and three pairs of subtelocentric autosomes with slight differences in size are countable. The metacentric chromosome $\mathrm{X}$ belongs to the longest chromosomes, the $\mathrm{y}$ chromosome is also metacentric but the shortest one (Fig. 2e). A small amount of centromeric heterochromatin appears during chromosome decondensation.

The karyotype of hitherto examined species from the family Curculionidae are characterized mainly by a small amount of heterochromatin. All chromosomes obtained from spermatogonial cells possess C-banded segments well visible during pachytene and diplotene and hardly visible or undetectable during the mitotic metaphase, diakinesis, metaphase I and II (Rożek et al. 2004). In such species the C-banding patterns cannot be used in taxonomic investigations and for differentiation of similar standard karyotypes. The absence of Cbands does not indicate the lack of heterochromatin but the heterochromatic regions are sometimes so small that the condensation is not visible during the cell cycle. The critical mass for C-band positive staining should be between 10.5 and 17.5 $\mathrm{Mb}$, also the number of repeats determines the staining properties of heterochromatic DNA (Redi et al. 2001). It also seems that application of fluorochome staining, eg. DAPI or CMA3, will not be practical tools for identification of heterochromatic parts of chromosomes.

Silver staining has been extensively applied for identifying the nucleolar organize regions (NORs) on mitotic chromosomes but also this procedure can be used to visualize the transcriptional activity of rRNA genes during meiosis (GoodPasture and Bloom 1975). Representative karyotypes with active NORs of the 4 species are shown in Figures $3 \mathrm{a}-\mathrm{d}$. According to some authors the NORs in Coleoptera are widely distributed in one autosome pair (VIRKKI 1983; VIRKKI et al. 1984). In all examined species the one Ag-stained NOR situated in the sex chromosomes is visible during mitotic and meiotic prophases and it may support the classic hypothesis of the nucleolar origin of the $\mathrm{Xy}_{\mathrm{p}}$. In insects, the distribution of NORs is variable - at premeiotic stages and early meiosis NORs are very active and in these stages they are always well visible. Most frequently they become invisible at meiotic metaphase I, metaphase II, and at mitotic metaphase. The absence of silverstained NORs in these stages could be explained by taking into account the high condensation of chromatin (MARYAŃSKA-NADACHOWSKA et al. 1992). Silver staining reveals transcriptional active NORs, in contrast fluorochrome CMA3 staining labels NORs independently of their activity and fluorescence is associated with high GC content (KuZnetsova et al. 2001). Unfortunately there are no information about the chromosomal location of rDNA genes in weevils.

\section{CONCLUSIONS}

The examined species from the genus Barypeithes share almost the same chromosome number but they are diversified in morphology of chromosomes as well as in amount and localization of constitutive heterochromatin.

Seven of eight analysed species possess 22 chromosomes, only endemic B. liptoviensis has additional four autosomes. The most asymmetric karyotype occurs in B. mollicomus, the chromosomes of B. cheurolati, and B. formaneki are slightly differentiated in the length, whereas the most symmetric karyotype is characteristic for $B$. pellucidus, B. interpositus, B. albinae, B. liptoviensis and B.purkynei. The chromosomes are mainly meta-, submeta-, and subtelocentric, only in B. interpositus and $B$. albinae subtelocentric chromosomes are absent. It seems that in the genus there is tendency towards symmetrization of karyotypes.

The constitutive heterochromatin appears almost in the centromeric region, and in three species - B. chevrolati, B. interpositus B. liptoviensis also in intercalary and terminal position. In five species the amount of heterochromatin is large and therefore C-bands are visible during mitotic metaphase. 

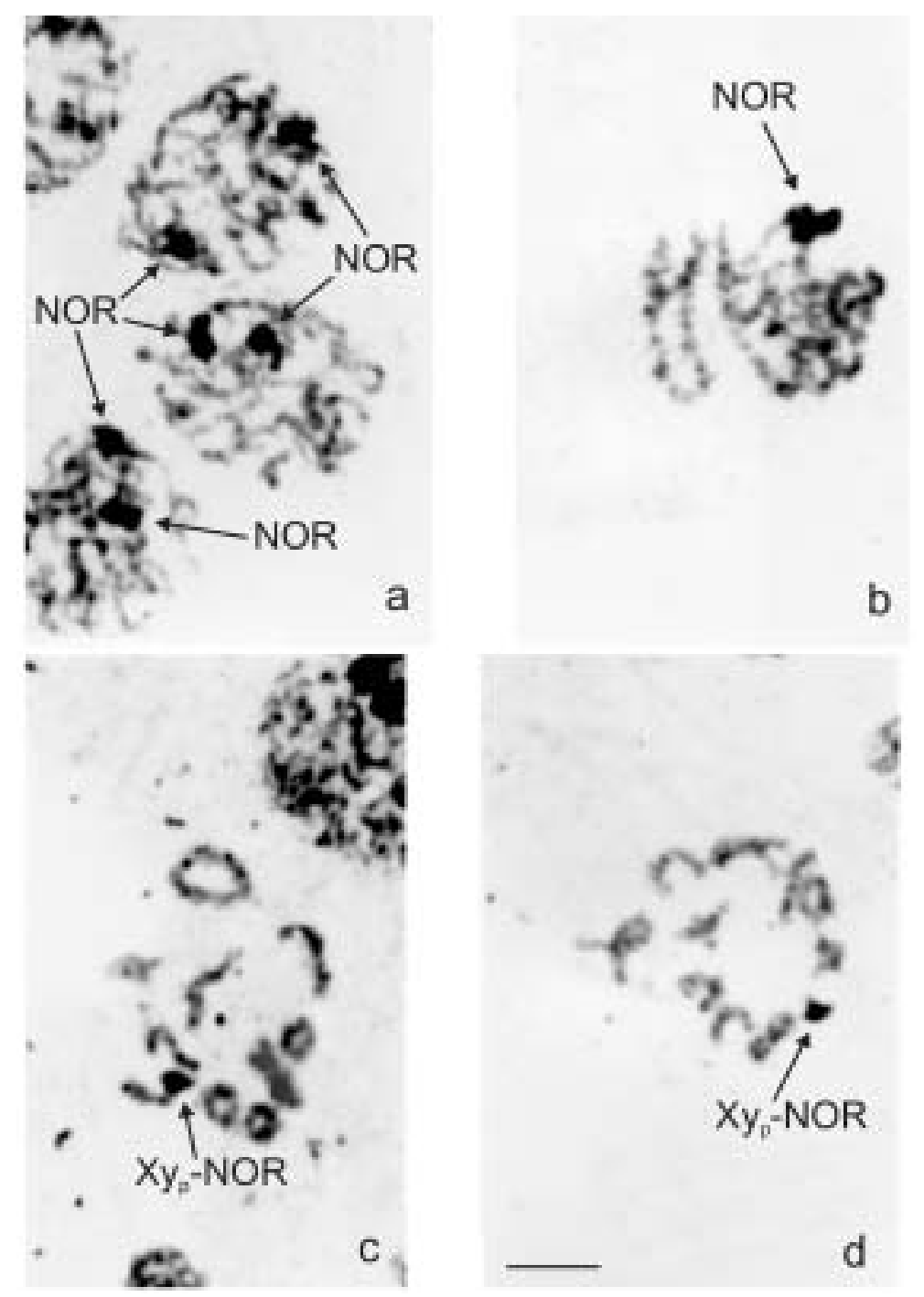

Fig. 3 - AgNOR stained chromosomes of Barypeithes species: (a) mitotic prophase of B. chevrolati, (b) early diplotene of $B$. formaneki, (c) diakinesis of B. interpositus, (d) diakinesis of B. pellucidus. Bar equals $5 \mu \mathrm{m}$.

In Barypeithes only one NOR activity is noticeable at early stages of meiotic prophase. Occurrence of some differences between Barypeithes species opens up new fields for molecular studies in the genus.

Acknowledgements - This research was supported by KBN (State Comitee for Scientific Research), grant number 3P04C 08525 and by VEGA (Scientific Grant Agency of the Ministry of Education and the Slovak Academy of Sciences), grant number 1/0119/03.

\section{REFERENCES}

Cross J.V., Easterbrook M.A., Сrook A.M., Сrook D., Fitzgerald J.D., Innocenzi P.J., Jay C.N. and
Solomon M.G., 2001 - Review: Natural enemies and biocontrol of pests of strawberry in Northern and Central Europe. Biocontrol Science and Technology, 11: 165-216.

DeY S.K., 1989 - B-chromosomes in two species of Indian weevils (Coleoptera: Curculionidae). Cytobios 57: 15-18.

DieCKMANN L., 1980 - Beiträge zur Insektenfauna der DDR: Coleoptera - Curculionidae (Brachycerinae, Otiorbynchinae, Brachyderinae). Beitr. Ent., Berlin, 30: $145-310$.

ENNIS T.J., 1972 - Low chromosome number and post reductional X0 in Gelus californicus (Lec.) (Coleoptera: Curculionidae). Can. J. Genet. Cytol. 14: 851857.

Fremuth J., 1971 - Die mitteleuropäschen Arten der Gattung Barypeithes Duval (Coleoptera, Curculionidae). Annot. Zool. Bot. Mus. Nat. Bratislava, 65: 1-30. 
Goodpoasture C. and Bloom S.E., 1975 - Visualization of nucleolar organizer regions in mammalian chromosomes using silver staining. Chromosoma, 53: 37-50.

Holecová M., Rożek M. and Lachowska D., 1999 Karyological investigations on ten species of weevils from Central Europe (Coleoptera: Apionidae, Curculionidae). In R.C. Sobti and J.S Yadav (Eds.), "Some aspects on the insight of insect biology". Narentra Publishing House, New Delhi, p. 189193.

Holecová M., RożeK M. and Lachowska D., 2002 Heterochromatic banding patterns on chromosomes of twelve weevil species (Insecta, Coleoptera, Curculionoidea: Apionidae, Curculionidae). Folia biol. (Kraków), 50: 129-134.

Holecová M., Rożex M. and Lachowska D., 2005 Evidence of B-chromosomes in karyptype of Barypeithes pellucidus Bobeman 1834 (Coleoptera, Curculionidae, Entiminae) from Central Europe. Folia biol. (Kraków), 53: 65-68.

Howell W. and Black D.A., 1980 - Controlled silver-staining of nucleolus organizer regions with protective colloidal developer: a 1-step method. Experientia, 36: 1014-1015.

Kuznetsova V. G., Westendorff M. and Nokkala S., 2001 - Patterns of chromosome banding in the sawfly family Tenthredinidae (Hymenoptera, Sympbyta). Caryologia, 54: 227-233.

Lachowska D., Holecová M. and Rożek M, 1998 Karyotypic data on weevils. Folia biol. (Kraków), 46: 129-136.

Levan A., Fregda K. and Sanberg A., 1964 - Nomenclature for centromeric position on chromosomes. Hereditas, 52: 201-220.

MARYAŃSKA-NADACHOWSKA A., WARACHA£OWSKAŚliwa E. and Kuznetsova V.G., 1992 - The NOR and nucleolus in the spermatogenesis of Psyll alni (L.) (Homoptera) analysed by silver staining. Folia biol. (Kraków), 40: 41-45.
Redi C.A., Gragna S., Zacharias H., Zuccotti M. and Capanna E., 2001 - The other chromatin. Chromosoma, 110: 136-147.

RożEK M., 1994 - A new chromosome preparation technique for Coleoptera (Insecta). Chromosome Research, 2: 76-78.

RożeK M. and LAChowska D., 2001 - C-bands on chromosomes of four beetle species (Coleoptera: Carabidae, Silphidae, Elateridae, Scarabaeidae). Folia biol. (Kraków), 49: 179-182.

Rożex M., Lachowska D., Petitpierre E. and Holecová M., $2004-C$-bands on chromoosmes of 32 betle species (Coleoptera: Elateridae, Cantharidae, Oedemeridae, Cerambycidae, Anthicidae, Chsysomelidae, Attelabidae and Curculionidae). Hereditas, 140: 161-170.

SMith S.G. and Brower J.H., 1974 - Chromosome numbers of stored-product Coleoptera. J. Kansas. Entomol. Soc. 47: 317-319.

SMreCZyŃski S., 1966 - Weevils - Curculionidae. Subfamilies Otiorbynchinae, Brachyderinae. Keys for identification of Polish insects. PWN, Warszawa (In Polish).

Sumner A.T., 1972 - A simple technique for demonstrating centromeric heterochromatin. Experimental Cell Research, 75: 304-306.

TAKenouchi Y., 1965 - Chromosome survey in thirtyfour species of bisexual and parthenogenetic weevils of Canada. Can. J. Genet. Cytol., 7: 663-687.

VIRKkI N., 1983 - Banding of Oedionychina (Coleoptera: Alticinae) chromosomes: C and Ag-Bands. J. Agric. Univ. Puerto Rico, 67: 221-225.

Virkki N., Flores M. and Escudero J., 1984 - Structure, orientation and segregation of the sex trivalent in Pyrophorus luminosus (Coleoptera: Elateridae). Can. J. Genet. Cytol., 26: 326-330.

Received 20.4.2005; accepted 2.5.2005 